\title{
The Development of Literature on Missionaries in the Turkish Language
}

\author{
Cemal Yetkiner*
}

\begin{abstract}
This article surveys how Turkish writings on missionaries developed chronologically and contextually over the years. It focuses on publications over three periods in the history of modern Turkey beginning with publications from the late 1920s and the 30s, which are studied as early examples of Turkish writings on missionaries. It also analyses the second wave of anti-missionary writings which came during the 1950s and 1960s. Lastly, this work looks at the writings on missionaries during the 1990 s and early 2000s. These publications represent the elements of the general literature on missionary activities in modern Turkey, which are generally colored with nationalist sentiments in a broad sense. Although some of the works studied in this article might not be considered as academic as others in terms of their methods of approach, they are still very important in allowing us to better understand the development of the history of the intellectual discussions amongst Turkish writers on missionaries and their roles in the past and present. This study is an attempt to build a parallel correlation over three periods in order to better understand the roles of missionaries, the spaces they built and their status in the collective memory of Turkish people.
\end{abstract}

Keywords: Religion, Politics, Missionaries, Social History, Anti-missionary Writings, Modern Turkey.

Öz: Bu makalede genel Türk literatürünün "Türkiye'de misyonerlik faaliyetleri" olgusuna metodolojik ve konusal açıdan nasıl yaklaştığı incelenmiştir. Makaleye konu olan bu eserlerin ne tür bir içerik ve nasıl bir yöntem çerçevesinde geliştiklerine bakılmıştır. Cumhuriyet tarihi boyunca "misyonerlik" üzerine yazılan çeşitli eserler kronolojik ve konusal açıdan üç ayrı dönem içerisinde incelendi. Birinci bölümde, 1920-1930'lu yıllarda basılan eserler ele alındı. İkinci bölümde, 1950 ve 1960 'lar dönemi ve misyoner karşıtı olarak gelişen eserler analiz edildi. Son bölümde ise, 1990'lar ve özellikle 2000'lerde çoğalarak hayat bulan yeni dönem eserlerin üzerinde duruldu. Her ne kadar bu eserlerin bir kısmı akademik dil ve disiplin içerisinde kalınarak yazılmamış olsa da; "Türkiye'de misyonerler ve misyonerlik faaliyetleri" üzerine oluşturulmuş bir literatürün parçaları olarak görülmeleri bakımından önem teşkil etmektedir. Genel olarak milliyetçi bir dile sadık kalınarak yazılan bu eserlerin konusal ve kronolojik açılardan incelenmesi bizlere, Türkiye'de misyonerlik faaliyetlerine olan entelektüel bakışın tarihsel sürecini anlamada yardımcı olacaktır.

Anahtar Kelimeler: Din, Politika, Misyonerler, Sosyal Tarih, Misyoner Karşıtı Eserler, Modern Türkiye.

* Assist. Prof. Adjunct., The City University of New York, Department of Middle East History.

Correspondence: yetkinercemal@hotmail.com. Address: 2012 31st Street, APT\#3C, Astoria, NY 11105, USA.

Atıf(: Yetkiner, C. (2014). The development of literature on missionaries in the Turkish language. Insan \& Toplum, 4(7), 163-178.

DOI: http://dx.doi.org/10.12658/human.society.4.7.M0086 


\section{Introduction}

This work studies the responses found in Turkish writings to missionaries. Although there are writings on missionaries dating back to the time of the Ottoman Empire, this paper only focuses on the literature written during the Republic of Turkey. It surveys how Turkish writings on missionaries have developed chronologically and contextually throughout the history of modern Turkey. Specific focus is given to publications over three periods: 1930s, 1960s, and the late 1990s and early 2000s. The works produced during these years are broadly colored with nationalist sentiments. This study suggests that building a parallel correlation over three periods helps us better understand the roles of missionaries, the spaces they constructed, and the collective Turkish memory of missionaries. The writings of these authors are now being discussed, challenged, and questioned by many scholars.

Study of missionaries in modern Turkey, particularly on French-Roman Catholic and British-American Protestant missionary accounts, goes back to the early 1930s. At that time, the one-party regime of Cumhuriyet Halk Partisi (CHP) (the Republican People's Party (RPP)), was in the process of constructing a nation. They were building the nation along the lines of the Altı $O k$, the "six arrows" that represented the principles of Mustafa Kemal Atatürk, the main architect of modern Turkey. ${ }^{1}$ As proposed by the new Republican elite, the nation would be a new political, economic, cultural as well as social and historical entity. It would also be devoid of the Ottoman heritage and distinguished from the modern Middle Eastern context. Instead, the nation would follow a course patterned after the secularist and republican idealism of Western Europe. Accordingly, the RPP developed various policies and implemented them throughout the second part of the 1920s and into the 1930s.

In order to construct a nation with historical continuity and to place the history of Turkey and Turks in a broad spectrum, Türk Tarih Kurumu, the Turkish Historical Society, was founded in April 1930 with sixteen members. It was set up to serve the republican interests of the new elite. The Turkish Historical Society was initially a dependent body of the Turkish Hearth Central Council under the name of Türk Ocağı Türk Tarihi Tetkik Encümeni. Within a short period it produced a number of works related to Turks in general, and Turkey in particular. It also inspired many others to study the history of a variety of topics relevant to modern Turkey in the years to come. ${ }^{2}$

1 For the history the Republican People's Party, see (Bila, 1979; Bozkurt, 1968; Rubin, \& Heper, 2002; Yetkin, 1983).

2 For the emergence of the "official history" thesis in Turkey, see (Copeaux, 1998; Ersanlı, 1992). 


\section{The First Turkish Writings on Missionaries; 1920s-1930s}

Within this context some of the earliest works on missionaries in Turkey appeared. Although they do not offer much in depth information in relation to the historical background of missionary encounters in the Ottoman Empire and modern Turkey, they nonetheless turned out to be the basis of many later works in the 1950s and especially in the 1960s. Misyonerlere Cevap ve Gençliği lykaz (Response to the Missionaries and Warning to the Youth) [1933], by Ali Ulvi Elöve, can be viewed and discussed against this ideological backdrop. In response to missionaries' long-lasting encounters with the people of the region, Elöve wrote a number of articles in the early 1930s on various topics related to beliefs, religions, and missions. The above mentioned book is a collection of these articles, published along with a special section titled "warning to the youth." Most of the articles in his study deal with the issue of "religion and belief." These articles focus primarily on his ideas in answer to questions such as "What is religion?" "What is the source of power in religion?" "What is the belief of God?" "What is sin?" and last but not the least "Life after death."

According to Elöve, missionaries travel the world with a certain missionary purpose and sense of effort. The prime purpose of their mission, he argues, is to spread Christianity. He adds that if that is not possible, then, they work toward diminishing nationalist feelings in the host countries and creating an environment of sympathy towards Christianity and Europeans. He also states that there are only a few countries left on earth not colonized after having had missionaries open a mission field in their lands and begin work amongst the natives. In order to "save" missionaries from "discouraging and disappointing" results, he offers the path of the religion of Islam, the belief and the doctrines of its messenger, Prophet Mohammed, and its holy book, the Quran, as real sources of ultimate salvation (Elöve, 1933, pp. 79-85).

In the second part of the book, Elöve gives warning to the youth of Turkey: "In order to confuse you and make you forget your own personality and identity," he starts his address, "Jesuits and other missionary priests are working very hard." There is no systematic organization in Turkey, he believes, "to stop missionary activities and prevent losing you [the youth] amongst them." According to him, "morality" was in decline in Turkey (his book was published in 1933). It is evident and easy to predict the dangerous future of those nations who had lost their "morality." In order to avoid missionary influence amongst the youth of Turkey and to construct a healthy future, he offers the study of positive science and, equally, spiritual education as the most important tools. Since the Quran was now translated into Turkish, he suggests the youth should read it and understand their religion as correctly as possible. In order to discipline the body morally, the most imperative rule, according to him, is to be a pious individual. Once we truly understand the religion of Islam, he states in his closing lines, we then may spread it to our friends and neighbors to have a collective and true consciousness (Elöve, 1933, pp. 86-89). 
Elöve published his work in 1933 in Istanbul at a time when various segments of Turkish society had already gathered openly and collectively to protest against missionary activities in large cities such as Istanbul and Ankara. For instance, it was popular among the students at Istanbul University to attend missionary talks in different parts of Istanbul and then write about the experience and, if possible, have their work published. These efforts notwithstanding, it was a group of Turkish journalists who explicitly rallied against missionaries and their activities in Turkey, in 1929. Initially united under the name of Türk Matbuat Birliği, "the Turkish Print Union", they later named their society Misyonerleri Kovma Cemiyeti ("-Missionary Expulsion Society-") in order to raise common awareness to the continuing religious activities of the missionaries in the newly emerging Turkish Republic. It was thought that press and printed materials would be the best tools to achieve the ambition of raising awareness using methods similar to those of the missionaries.

On May 9, 1929 Cumhuriyet (Republic) newspaper printed the following news to its readers across Turkey:

Yesterday, the members of the Missionary Expulsion Society gathered for the first time at the Printing Society. The purpose of the Missionary Expulsion Society is to prevent a life's chance for missionaries who are being used as agents of imperialist states and for their plans in the Turkish lands, and for those active for the Christian missionary propaganda... The Society will specially give emphasis to publications (Güngör, 2005, p. 100). ${ }^{3}$

Soon after their unification, the journalists' emphasis on publications was realized. Resimli Ay Mecmuası, then a monthly illustrated magazine, published one of the first articles in its May 1929 edition. "Kızımı Amerikan Kız Kolejine Nasıl Verdim, Ne Hâlde Aldım?" (How I gave my daughter to the American College for Girls, and in what condition I took her back?) The article gave the story of a father who enrolled his daughter in one of the best western educational institutions of the time. He witnessed in a short time how her behaviors, habits, and perceptions were quickly transformed. She altered her feelings of being a "Turk" in favor of becoming a "cosmopolitan" individual through educational and cultural processes in the American Girl College ("Kızımı Amerikan Kız Kolejine", 1929, pp. 18-40).

\section{The Second Wave of Anti-Missionary Writings; 1950s-1970s}

In the following decades, many similar publications emphasized missionary activities in Turkey in contemporary perspectives. Examples include $\mathrm{H}$. Tahsin Başak, Misyonerlere ihtar, (Warning to the Missionaries) 1953; O. N. Bilmen, Bir Amerikalının Suallerine 
Cevaplar (Kırk Cevap), (Answers to the Questions of an American (Forty Answers) 1956; Erol Kırşehirlioğlu, Türkiye'de Misyoner Faaliyetleri, (Missionary Activities in Turkey) 1963; Enver Baytan, Hristiyan Misyonerleri Nasıl Çalışıyor, (How Christian Missionaries Work) 1965; M. Kemal Pilavoğlu, Dünya Dinleri ve Misyonerlik, (World Religions and Missionary) 1966; Musa Çakır, Anadolumuz Asla Hristiyan Olmayacak: Misyonerler Memleketinize Dönünüz, (Our Anatolia will never be Christianized: Missionaries! Return to your Country) 1966; Samiha Ayverdi, Misyonerlik Karşısında Türkiye, (Turkey Against Missionary) 1969 and last but not the least Abdülaziz Çaviş, Anglikan Kilisesine Cevap, (Response to the Anglican Church) 1974.

Many other names and parallel works in the period from the 1950s to 70s may well find their places in other, yet similar lists. In general, it is imperative to recognize them along the lines of horizontal and vertical continuity in "the history of missionary writing in Turkey." That is to say, writings about missionaries and their roles in Turkey have developed chronologically and contextually over the years. However, it has been contained and framed more or less within the same similarly-constructed methodological approaches and manner of perception. What these authors achieved in terms of contribution to missionary literature in Turkey, and by what means, is now debated, challenged and, in fact, questioned by many scholarly but fragmented approaches in and outside of Turkey. Nevertheless, they represent the beginning of the missionary literature in modern Turkey, and as such, were the first paradigms in that genre often colored with nationalist sentiments.

A chronological look at three of these works helps to elaborate the argument mentioned in the above paragraph. The first work, Türkiye'de Misyoner Faaliyetleri, was published in 1963 by Erol Güngör, under the name of Erol Kırşehirlioğlu. He was nineteen years old when he presented his work's original form version as a paper at a conference in Istanbul, in 1957, held by İstanbul Milliyetçiler Derneği (The Istanbul Nationalists Association). Six years later, he published it without (according to his own account) making changes to the original text. It is not an analytical study but a narrative on the history of the missionaries and their institutions in Turkey. He begins with the history of Christianity in the Middle East in general. He suggests that the first missionary activities in the region go back to the mid-eighteenth century and to the works of the Church of Moravia, now a province in modern Czech Republic. In his account, the first two missionaries - medical missionaries of the Church of Moravia, namely Mr. Hocker, a doctor, and Mr. Ruefler, a surgeon - began their journey to the East in 1747. They had hoped to reach Persia, today known as Iran. British, French, American, Dutch, and German missionaries of different denominations followed their footsteps throughout the nineteenth and twentieth centuries (Güngör, 2005, pp. 18-19). Güngör then turns to the missionary schools and institutions in Turkey. He portrays the brief histories of the American Girl College in Bursa, the Robert College of Istanbul, French Saint Benoit 
High School, Young Men's Christian Association (YMCA), Armenian schools, and, lastly, hospitals in the region in connection with missionaries. He concludes his work with his thoughts regarding Christian cultural propaganda in modern Turkey

According to Güngör, the Muslim world and Turkey in particular were faced with a systematic and organized danger (in his words, a "Christian threat"), and he asks "what can be done?" (Güngör, 2005, pp. 85-105). He outlines his suggestions based on immediate recovery from existing ignorance (cahiliyet) and the inattention of missionaries and their activities. According to him, the Christian threat was only one of the collective issues Turkey was then facing. He asserted that the current situation [the book was written in 1957], was not favorable to the Turkish people at all. In order to confront this threat, he advocates, first and foremost, the development of publications targeting missionaries and disputing missionary writings. Secondly, he suggests that a similar focus be applied to all kinds of Islamic publications, and then recommends the opening of various associations and societies to respond to the missionary organizations in Turkey. Subsequently, he advises the founding of new schools, and finally states the need of the Muslim missionaries in that regard (Güngör, 2005, p. 102).

As Güngör suggests, his book was not a scholarly work based upon research and analysis of available materials. Rather, it was a historical narrative of missionary encounters in Turkey. This narrative offers suggestions for countering contemporary examples of that process. Regardless of his argument (which echoed themes found in other books), his employment of English and French sources, along with some missionary works, reports, and secondary sources, made his work unique for its time.

The second work to be discussed was written by Musa Çakır, a teacher of religion. Published in 1966 in Istanbul, Anadolumuz Asla Hristiyan Olmayacak: Misyonerler Memleketinize Dönünüz summarizes Çakır's personal experiences. It narrates the story of his discussions with contemporary missionaries working in different districts of Istanbul, in 1964. In an observation similar to that made by others, he states that since the thirteenth century missionaries under various names had been trying to Christianize the nations of the world. According to him, missionary organizations were founded by imperialist nations for two purposes, these being identified as materialistic and spiritual. While these organizations exploit nations through the effects of the former, he states, their members believe in increasing their good deeds (and, thereby; chances for redemption in heaven) through the latter. Missionaries, Çakır notes, focus their attention and evangelical works particularly on underdeveloped nations in Asia and Africa. They are the warriors of imperialist nations with no physical weapons in hand. In his account, every imperialist state has its own missionary organizations. The list includes the United States, Great Britain, Portugal, the Netherlands, France, and Russia. The members of missionary organizations usually work as men of faith, teachers, doctors, nurses, and peace advocates (Çakır, 1966, p. 5). 
Çakır gave examples of how missionaries operated. In January 1964, he was invited by missionaries for a dinner at an apartment in Istanbul. He attended the dinner alongside some twenty students from various faculties and departments of Istanbul University. After a beautiful dinner service and coffee, Çakır recalls, two young men started a sermon about Jesus through translators. One was from Switzerland, the other from the Netherlands. According to Çakır, the missionaries preached that in order to have universal peace and serenity in heaven, people need to know Jesus and his teachings very well. These missionaries preached that Jesus sacrificed himself for the sins of all mankind and was the son of God. Christianity was the last religion, it was easy, met with the expectations of humanity, and ordered tolerance. Jesus never married and for the salvation of humankind, he dedicated himself to his father, God.

Çakır told how later in the sermon, the missionaries came to a point in which they started to talk about Turkey and Turks. According to the missionaries, Turkey had a glorious history, had introduced great names and figures into history, and was on the path of development, having recently entered European civilization. The missionaries strongly supported the development of modern Turkey. According to them, Islam as a religion and religious people, (sofular) prevented the further development of Turks. By contrast Atilla, a Turkish commander in the Hun dynasty and his Empire represented a great moment in Turkish civilization, according to the missionaries. If a rapid development is dreamed of today in Turkey, Turks need to get rid of religion immediately, and embrace full secularism.

One of the law school students then asked, "Well, let's say we put away our religion! What is next?" The missionary answered, "Examine the religions, you will choose a good one." "For instance?" the student again asked. Then the missionary continued his sermon and teaching along the following lines:

By now, it is well known which religion is convenient and suitable. If you look at the world today, the richest nations on earth are all Christian ones and Christianity is the largest religious group in the world. However, if you look at Atheists, Muslims, Buddhists, and others, they are all in underdeveloped countries. Let's look at Muslims: Syria, Egypt, Jordan, Indonesia, Malaysia, Pakistan, Tunisia, Algeria - they are all underdeveloped countries now. The only developing one is Turkey. If Islam was God's religion, do you think God would leave them in desperate poverty today? Christians, on the other hand, are in prosperity due to the fact that their religion is the true religion, and therefore God, the father, gives them all they need.

Çakır later described the atmosphere in the room. The students, many of whom would perhaps be holding important positions in Turkey in the future, were shaking their heads as if they were confirming the statements of the sermon and started talking to each other on the perspectives of the missionaries. This conversation lasted the rest of the night (Çakır, 2005, pp. 6-9). 
Later in the book, Çakır gives another example of meeting with missionaries, this time in Aksaray, a district in the European side of Istanbul, in the same year, 1964. The evening at the missionaries' apartment in Inkılap (Revolution) street in Aksaray started in the same order. After a delicious turkey dinner and coffee service, he recalls, the missionaries began their sermon in a manner similar to the last one but this time in Turkish. Çakır inquired if he might ask some questions. He had already prepared in his mind specific questions with respect to Christianity and Islam; allowing him the opportunity of opening a dialogue which would absorb all attendees for the rest of the night. Accordingly his questions were welcomed. His enquiries and the following discussion provided the ingredients for his book. ${ }^{4}$ According to him, after the questions they had a heated discussion, the night ended at around 4 a.m., and the attendees left the apartment with great excitement (Çakır, 2005, pp. 85-86). Later, in the conclusion, he outlines his suggestions on what can be done to stop missionaries and by what means. ${ }^{5}$ Musa Çakır's story is important in the sense that it helps us to imagine the kind of atmosphere that was there at the gathering. Moreover, it facilitates a picture of how missionaries interacted with the locals on a micro level, discussed here as representative of a wave of writing in the 1950s-1970s.

The third work, Misyonerlik Karşısında Türkiye, differs from the first two works discussed above. It is neither a historical study nor is it a personal narrative. It is based on a collection of six letters from Samiha Ayverdi written in regard to her complaints about ongo-

4 Çakır's questions to the missionaries were: What was the first Christian country? Why don't Christians follow the orders of Prophet Jesus? Is your religion the foremost reason of your economic wealth and positive science? Why are there four Bibles? Do you know the meaning of the word "Paraklit" (successor)? What does "Teslis" (holy trinity) mean and can you explain it? Why is Islam backward and reactionary, please explain? Why did the Prophet not marry and why was he sacrificed? Can you explain the justice and tolerance in Christianity and how? How do you know and can you describe Prophet Mohammed? (Çakır, 2005, p. 10).

5 His suggestions: 1- The Turkish elite, and government apparatuses and branches have to stop their disputes over many unnecessary issues immediately and focus on the economic development of the nation. 2- Measures have to be taken in order to improve brotherhood and national unity among the country's citizens. 3-Separatist movements have to be prevented and stopped. 4- Laws must prohibit all the missionary activities of all kinds of organizations originating from out of Turkey. 5- As missionaries are harmful for our nation, laws have to persecute them. 6- We must educate the religious elite, who have great knowledge and good manners. 7- We must give respect to the men of faith in the society. 8- We have to exclude all religious men from their posts who do not perform their duties properly. 9- We have to teach the masses and students to believe that religion is not a cause of backwardness. 10- We have to fully use all modern tools for that purpose. 11- Religious men should not preach only at mosques, but also need to be allowed to do so in the rest of the community. 12-We should not repeat the errors done in the past. 13- The state should take care of the problems at the village level right away. 14-The Office of the Religious Affairs should provide and distribute free or at a very low cost, religious books to the public. 15- We have to expedite the war on ignorance, cahiliyet. That is to say, educate the men and women of society as the Prophet Mohammed suggested. 16- We have to explain and teach people and make them understand that secularism is not an enemy of religion and practice it accordingly. 
ing missionary activities in Turkey. These letters were addressed to Raymond Kern, who was at that time the chair of the Protestant Missionary Organization based in Switzerland, between 1965 and 1967. She later published them in 1969 together with six response letters from the center. Samiha Ayverdi, born in 1905 in Istanbul, started her scholarly life as a novelist and in 1938 at the age of 33 published her first novel, Aşk Budur (This is Love). After 1946, she switched her attention toward more philosophical and historical subjects and produced several works. Like many others of her time, she had also been receiving many anonymous brochures, letters, and religious texts promoting Christianity. These were sent to homes, offices, schools, temples, and other places by the missionary centers. According to her, there is nothing to learn from Christianity in the Islamic world; therefore there is no need for missionaries in Muslim lands (Ayverdi, 2001, p. 9). She felt responsible to write directly to the missionaries.

On August 6, 1965, Ayverdi sent the first of her letters to the missionary center in St. François, Switzerland, entitled "The first letter to the Christian World on Mr. Kern's Behalf." "Dear Careless and Ignorant Christian Brothers!" she starts, asking "why are you bothering those of us who are the followers of the Prophet Mohammed and why don't you leave us alone?" Being Muslim, she argues, "we are already saved and have reached the true salvation. That is why we do not need your "good news," müjde, of salvation." On the contrary, she adds "you are the one who is indeed in need of salvation." She then suggests to the missionaries that "since you have a lot of money for your propagations and large organizational network, then why don't you stop propagating among the Muslims who recognize your Prophet, but employ and utilize your labor and money against Communism, which is not only the enemy of Muslims and Christians but that of all the other religions." Along these lines, she writes "we have a common enemy and we have to stop fighting each other and focus on our unification and work to cut the head of Communism, instead." It is now the time to say good-bye to the missionary mentalities of the Middle Ages. This Crusades approach is indeed weakening Christianity day after day. Rather than playing with beliefs and ethics she suggests, "listen to the warning bells next to you and turn your attention and activities towards that end. Then, this will be the salvation and good news, müjde, of the twentieth century to mankind."

On September 9, 1965 Raymond Kern sent his first letter to Samiha Ayverdi in hope of answering her and her questions of the truth. "We thank you very much for your interesting letter dated August 6," Kern begins with his opening, suggesting that they are happy to hear from her even though, her beliefs are contrary to their writings in missionary publications. "While we were reading your letter," he writes, "we did not have any difficulty to understand that you are a clever person and in thirst and search of God." There is no one throughout history who has started searching for the Truth without trying to know and understand all in that matter first. Therefore, he says, "if 
you see that there are enough evidences surrounding you to see Jesus and his truth then you are about to reach true salvation." In his closing lines, he wishes her the best and hopes that their materials along with his letter will help to answer her questions and support her spiritually (Ayverdi, 2001, pp. 35-36). Angry with the response and the publications she received, she sent her second letter to him on October 20,1965, suggesting that he could not or did not want to understand her at all. She puts forth her original comments one more time and offers an alliance against Communism. She also encloses this time her letter sent to Pope Paul the Sixth earlier, entitled "Complaint on Missionaries" (Ayverdi, 2001, pp. 37-44). The response from Kern arrived shortly and her new letter was sent out in return, which was followed by a new response, and so on. Through the new letters between 1965 and 1967, Ayverdi and Kern continued to talk philosophically about the history of Judaism, Christianity and Islam and their contradictory practicality, as well as the common threat of Communism to "humankind."

Over the course of the exchange, both parties were unable to convince the other of their positions regarding missionary formations in foreign lands. Additionally, they could not persuade each other regarding the practice of promoting Christianity and proselytizing among the Turks. After writing a long historical background on the Turks and their belief in Islam, Ayverdi suggests to Kern that "you are living in a fantasy world in which you have indeed lost yourselves and need true salvation" (Ayverdi, 2001, p. 143). Seeing that writing and sending materials to each other over the years did not achieve much in relation to missionary activities in Turkey, in her last letter on July 13,1967 , she recommended they discontinue their correspondence. She also advised that she might publish these letters soon, for the reason that others in the future may perhaps make use of the dialogue reflected in the words of the letters over two years (Ayverdi, 2001, pp. 150-151).

The above three depicted works represent examples of writings on missionaries in the 1960s in Turkey. Written by three different authors with three different backgrounds and methods, these collectively show how the authors of these works perceived missionaries in their times as the multifunctional "agents" of foreign lands. These works also express the interests against the nativity and authenticity of local entities across the world, such as those in Turkey. What unites them is also a similarity in their methods of seeing missionaries in general. It is a space in which they unite collectively for the perceived needs of their own times. In particular, these and many other works can be counted as early examples of a constructed literary consciousness in Turkey in response to the centuries-old missionary activities. 


\section{New Scholarly Approach to Missionaries; 1980s}

Before going into the last phase of missionary writing in Turkish literature and discussing some of the contemporary perspectives in the early 2000s, it is imperative here to mention a work entitled Kendi Belgeleriyle Anadolu'daki Amerika: 19. Yüzyılda Osmanlı Imparatorluğu'ndaki Amerikan Misyoner Okulları, (In its own documents, America in Anatolia: American Missionary Schools in the nineteenth century-Ottoman Empire), published in 1989 by Uygur Kocabaşoğlu. It is an in-depth research on nineteenth century American Protestant missionaries and their educational activities in Istanbul and the Anatolian hinterland (Kocabaşoğlu, 1989). It is one of the first scholarly approaches on the issue of missionaries and their role in the history of the Ottoman Empire and modern Turkey. What makes Kocabaşoğlu's work one of the most important classics on missionaries in Turkish literature is the fact that he was the first who extensively worked through the American Board of Commissioners for Foreign Missions' (ABCFM) archives in the Houghton Library of Harvard University. His contribution lies in the fact that through his study he introduced for the first time a great number of first-hand missionary archival documents to the Turkish reader. A graduate of an American missionary high school himself (Tarsus American College), he led the way and introduced tools for many (including his students like myself) to understand the missionaries and their times.

According to Kocabaşoğlu, American Protestant missionary movements in the nineteenth century cannot be distinguished from the greater imperial economic and political interests of the United States in what is called today the Middle East. He suggests that during the rise of American influence in Africa, Asia, South America, the Middle East and so on, missionaries and their organizations functioned as indispensable channels (Kocabaşoğlu, 1989, pp. 219-220). Not only did missionaries in the Ottoman Empire play significant roles in the process of spreading Protestantism among the people of the Ottoman Empire and introducing American culture, but they also made great efforts to understand the society that they sought to influence. He states that "when Ottoman intellectuals in the first quarter of the twentieth century began to "discover" Anatolia, American missionaries had already "mapped" it. And because they knew it well, they had insights into the values, patterns of behavior, desires, prejudices and expectations of different ethnic and social groups living there" (Kocabaşoğlu, 1989, p. 220). ${ }^{7}$ His work, therefore illustrates how missionaries worked through the arenas of the press, education, medicine, religion and so on in order to first map, then understand, and then influence. Finally, in the long run, this would lead to the formation of a "living space" among the old world orders as they expanded.

7 Quoted in Hans-Lukas Kieser, "Mission, Ethnicity and Civil Society in Ottoman and early Republican Turkey." This paper was read at the workshop Identity Formation and the Missionary Enterprise in the Middle East, Watson Institute for International Studies, Brown University, Providence RI, November 17-18, 1999. 


\section{Recent Writings on Missionaries; 21th Century}

The early 2000s witnessed the revival of writing on missionaries in Turkey. Various new works were published or old ones re-appeared in new editions within a short period of time. The list includes a variety of names correlated to missionary topics. Such were: Samiha Ayverdi, Misyonerlik Karşısında Türkiye (Turkey against missionary), 2nd ed., 2001; Şinasi Gündüz and Mahmut Aydın, Misyonerlik: Hristiyan Misyonerler, Yöntemleri ve Türkiye'ye Yönelik Faaliyetleri (Missionary: Christian missionaries, their methods and activities against Turkey), 2002; Necdet Sevinç, Osmanlı'dan Günümüze Misyoner Faaliyetleri: Okullar, Kiliseler, Yardım Kurumları (Missionary activities from Ottoman period to the present: Schools, churches, charity foundations), 3rd ed., 2002; Erdal Açıkses, Amerikalıların Harput'taki Misyonerlik Faliyetleri (American missionary activities in Harput), 2003; Ali Rıza Baysan, Küresel Vaftiz: Misyoner Örgütlerin Türkiye ve Türk Cumhuriyetlerini Hristiyanlaştırma Operasyonu (Global baptize: Christianization operation of missionary organizations for Turkey and the Turkic Republics), 2nd ed., 2004; Süleyman Büyükkarcı, Türkiye'de Amerikan Okulları (American schools in Turkey), 2004; Ahmed Yüksel Özemre, Din ve Misyonerlik (Religion and missionary), 2004; Erol Güngör, Türkiye'de Misyonerlik Faaliyetleri (Missionary activities in Turkey), 3rd ed, 2005; Hulki Cevizoğlu, Misyonerlik ve Siyasal Hristiyanlık (Missionary and political Christianity), 2005; Ömer Faruk Harman, ed., Türkiye'de Misyonerlik Faaliyetleri (Missionary activities in Turkey), 2005; Uğur Yıldırım, Dünü, Bugünü, l̇çyüzü ve Perde Arkasıyla Türkiye'de Misyonerlik (Mission in Turkey with its past, present, inner face and behind screen), 2005; Uğur Yıldııım, Türkiye'de Misyonerlik Faaliyetleri (Missionary activities in Turkey) $5^{\text {th }}$ ed., 2005. Şamil Mutlu, Osmanlı Devleti'nde Misyoner Okulları (Missionary schools in the Ottoman state), 2005.

One of the reasons for this rapid increase in publications about missionaries is because many (archival) missionary documents and secondary sources became much more easily available in Turkey and abroad. Another reason can be found in the symbiotic relationship between America's greater preparation for the project of re-shaping and re-ordering the Middle East after the September 11, 2001 attacks and the subsequent rise of nationalism and Islam in Turkey and across the region. In response to this interaction, scholarly interest in the past and present relationship of the "two worlds" (Christian/West versus Muslim/Middle East) developed very rapidly. This resulted in writings about various topics in Turkey, some of which covered missionary movements. Above all, controversial policies of some European countries, such as France, Belgium, and Germany, against the accession of Turkey into the European Union inevitably led to the rise of nationalism, or as called by some today, "ultra nationalism" in Turkey. This, as well, became a further practical reason for the general interest of the public in nationalist publications. These publications include topics based on and related to the missionaries and their on-going activities in the former Ottoman Empire and modern Turkey. 
Similar to the earlier generations of the 1930s and 1960s, the authors of these abundant interpretations also share a common way of seeing and understanding the missionaries and their roles in history. Collectively, most of the works label the missionaries as the agents and or the cultural or imperial ambassadors of the major powers in the world today. For instance, in the introductory section of the new edition (2001) of Samiha Ayverdi's work, Misyonerlik Karşısında Türkiye, Dr. Orhan Seyfi Yücetürk argues that recently missionaries rediscovered the vacuum in Turkey because of the crises within Islamic and national cultural life. This, therefore encouraged the missionaries to fill the gap and work among the Turks. According to him, proselytizing among the Turks forms a danger to national unity. This development shows that missionaries have imperialist agendas in conjunction with religious purposes. The purpose of missionary activities in Yücetürk's view displays special economic, political, and cultural circumstances. He also argues that missionaries are always working with Churches, states, political establishments, and industrialists for greater purposes. Consequently, he suggests it should be the obligation of every intellectual and sincere Muslim Turk to stand against missionaries today (Ayverdi, 2001, pp. 3-6).

In his comprehensive work on the American missionary activities in Harput (MamuratülAziz) and their activities on a micro level, Amerikalıların Harput'taki Misyonerlik Faliyetleri, Erdal Açıkses also sees the missionaries as tools and vehicles of Western powers. He states that throughout history, missionaries were used as tools by various states which had influences over the educational, cultural, political, and social structure of Turkey. Furthermore, he notes his belief that it is now impossible to say that Christian countries did not succeed in their ambitions (Açıkses, 2003, pp. 7-8).

In 2004, another work was added to the growing debate on missionaries in Turkey: Küresel Vaftiz: Misyoner Örgütlerin Türkiye ve Türk Cumhuriyetlerini Hristiyanlaştırma Operasyonu, by Ali Rıza Bayzan. In this work, Bayzan argues that in reality, there is not any "naive" Christian individual who likes to share his/her truths with us in the name of mission today. As he states, we are not confronted with individuals as "missionaries" alone; on the contrary, we are faced with missionary institutions in general as collective organizations. He writes that alongside their religious activities, missionary organizations work strategically and systematically in political, economic, social, and cultural areas. "Global giants" (he means major political powers) provide all kinds of logistic support to missionary institutions in foreign lands. To support his argument, he sketches the connections of all of the participants in this network of interests and presents his evidence.

According to Bayzan, missionary organizations came to the Turkish Republic during five historical periods. The first of them was after World War II, through the process of 
the Marshall Aid Program of 1948. The second period in which missionaries entered Turkey freely was in the time of Turgut Özal's economic opening of policies to the West during the 1980s. This period, Bayzan notes, witnessed the restorations of many Protestant and Catholic churches across Turkey, as Turkey developed and increased its contacts further with the West. The third phase of missionary activities in Turkey occurred right after the earthquake in 1999, under the aid process to the victims of this tragic incident. The fourth stage was in the course of religious tourism to the ancient Christian lands in 2000 and 2001, in which missionaries found ways to reach Turkey. The last step, he points out, is now taking place during the integration and negotiation process of Turkey with the EU (Bayzan, 2004, pp. 8-12).

In 2005, many new books and articles were published in relation to missionaries and their roles in Turkey. They primarily deal with various missionary groups and their activities in historical and contemporary perspectives. In his work, Dünü, Bugünü, içyüzü ve Perde Arkasıyla Türkiye'de Misyonerlik, Uğur Yıldırım looks at Protestant missionary activities in general, stating they are supported by the United States and the European Union today. He specifically stresses the religious activities of missionaries, their home Churches across Turkey, the activities of the Vatican in Turkey, and the project commonly called the "inter-religious dialogue." According to him, missionary activities have never been a religious matter alone in any period of history. Missionary organizations were first used during the attempts by Crusaders to persecute the Turks of Anatolia. Then they were employed under the patronage and orders of occupying powers during the Turkish war of independence in the early twentieth century, and finally, now, they are working as the agents of the West. Missionaries are an integral part of Western policies and strategies in Turkey. Throughout their history, he notes, missionary organizations marched side by side together with the exploitation process. They are backed and supported by the intelligence services of the imperialistic powers and multinational partnerships and companies. It is totally a political matter, he suggests, and notes that it is directly interrelated to the national security of Turkey today. Missionaries, Yıldırım points out, work today not for the creation of new minorities through converts, but rather work for the construction and formation of "Christian and Protestant Turks" who truly belong to the West with all the rights and privileges entitled to them by Turkish citizenship (Yıldırım, 2005, pp. 15-16).

Also in 2005, a new edited work was published as an outcome of the papers presented in a conference called "Missionary Activities in Turkey." The conference was organized by the Islamic Science Research Institute in Istanbul and held on April 17-18, 2004. Edited by Prof. Dr. Ömer Faruk Harman, Türkiye'de Misyonerlik Faaliyetleri contains thirteen papers delivered in the conference together with discussion sections for each paper. In a two-day conference, participants presented their papers and discussed various topics, such as Missionary in General, Changes of Missionary Methods, the 
Past and Present of Catholic Missionary against Turkey, Orthodox and Protestant Missionary Activities in Turkey, the Mormons and their Church, Missionary Activities against the Minorities in Turkey, the Missionary Understanding of Judaism, Bahaism (a Persian Sect in Islam) and Bahai Activities in Turkey, the Activities of Religions in Turkey originating from India, Working methods of Missionaries, Socio-physiological Reasons for Converting to other Religions, and Missionary Activities and our youth.

Most of the papers were based on a variety of archival and secondary sources. The conference presents the readers with a large number of papers and a wide range of topics with respect to missionary activities in Turkey. Based on their arguments, findings and proofs, most of the papers view the missionaries as the agents of imperial designs on the Ottoman Empire and modern Turkey. Missionaries are not seen as people of religion who teach their own truths to others, but as people also charged with working collectively for other ends. As Prof. Dr. Abdurrahman Küçük argues, missionaries appear sometimes as academicians, sometimes as people of religion, sometimes as military personnel, sometimes as members of medical units, even as peasants. They sometimes go to foreign lands as aid workers, experts on earthquake relief efforts, as members of the press, and sometimes as peace advocates. Moreover, according to him they do not go to these places accidentally. He points out that everything is based on plans which date back to the 1640s to conquer the Turkish nation from the inside through missionary activities. He states that, missionaries work for and dream of a Muslim world without Turks, a Turkic world without Turkey, and a Turkish nation without Islam (Harman, 2005, pp. 39-59).

\section{Conclusion}

The analysis of the afore-mentioned articles and books shows how Turkish writing on missionaries developed chronologically and contextually over the years. Specific focus was given to publications over three periods above, (1930s, 1960s, and early 2000s), demonstrating that these works represent the general literature on missionaries in modern Turkey. These are continuities in the approaches of Turkish literature to the roles of missionaries. Although few writings are sympathetic to the missionaries, it should be acknowledged that the corpus of writings on missionaries in Turkey has been formed with nationalistic sentiments. They are colored with nationalist feelings across a broad spectrum for various and complex reasons. Writings over the last seventy years on missionaries and their roles in history have often walked a delicate line between scholarship and ideology but their method of seeing the missionaries in history echo through Turkish scholarship today. 


\section{References}

Açıkses, E. (2003). Amerikalıların Harput'taki misyonerlik faaliyetleri. Ankara: Türk Tarih Kurumu Basımevi. Ayverdi, S. (2001) Misyonerlik karşısında Türkiye. İstanbul: Kubbealtı Neşriyatı.

Bayzan, A. R. (2004). Küresel vaftiz: Misyoner örgütlerin Türkiye ve Türk Cumhuriyetlerini Hristiyanlastırma operasyonu. İstanbul: IQ Kültürsanat Yayıncılık.

Bila, H. (1979). CHP tarihi. Ankara: Doruk Matbaacılık Sanayi.

Bozkurt, C. (1968). Siyasi tarihimizde CHP: Dünü, bugünü, ideolojisi. İstanbul: N. P.

Copeaux, E. (1998). Tarih ders kitaplarında (1931-1993) Türk tarih sentezinden Türk-İslam sentezine (Trans. A. Berktay). İstanbul: Tarih Vakfı Yurt Yayınları.

Çakır, M. (1966). Anadolumuz asla Hristiyan olmayacak; misyonerler memleketinize dönünüz. İstanbul: Bedir Yayınevi.

Elöve, A. Ü. (1933). Misyonerlere cevap ve gençliği iykaz. İstanbul: Burhaneddin Matbaası.

Ersanlı, B. B. (1992). Iktidar ve tarih: Türkiye'de "resmî tarih" tezinin oluşumu, 1929-1937. İstanbul: Afa Yayınları.

Gündüz, Ş. G. \& Aydın, M. (2002). Misyonerlik: Hristiyan misyonerler, yöntemleri ve Türkiye'ye yönelik faaliyetleri. İstanbul: Kaknüs Yayınları.

Güngör, E. (2005). Türkiye'de misyoner faaliyetleri. İstanbul: Ötüken Neşriyat.

Harman, Ö. F. (2005). Türkiye'de misyonerlik faaliyetleri. İstanbul: Ensar Neşriyat.

Kırşehirlioğlu, E. (1963). Türkiye'de misyoner faaliyetleri. İstanbul: Bedir Yayınları.

Kızımı Amerikan Kız Kolejine nasıl verdim, ne hâlde aldım? (Mayıs, 1929). Resimli Ay Mecmuası, 18-40.

Kocabaşoğlu, U. (1989). Kendi belgeleriyle Anadolu'daki Amerika: 19. yüzyılda Osmanlı Imparatorluğu'ndaki Amerikan misyoner okulları. İstanbul: Arba Yayınları.

Rubin, B., \& Heper, M. (Ed.). (2002). Political parties in Turkey. London: Frank Cass.

Yetkin, Ç. (1979). Türkiye'de tek parti yönetimi. İstanbul: Altın Kitabevi.

Yıldırım, U. (2005). Dünü, bugünü, içyüzü ve perde arkasıyla Türkiye'de misyonerlik. İstanbul: Otopsi Yayınları. 